\title{
Loss \& Damage: a Critical Discourse Analysis of Parties' Positions in Climate Change Negotiations
}

\author{
Elisa Calliari
}

Fondazione Eni Enrico Mattei, Euro-Mediterranean Center on Climate Change, Ca' Foscari University, Venice, Italy, and International Institute for Applied Systems Analysis, Laxenburg, Austria

\author{
Corresponding Author: \\ Elisa Calliari \\ Fondazione Eni Enrico Mattei (FEEM) \\ Isola di San Giorgio Maggiore 8, 30124, Venice, Italy \\ Phone: +39041 2700457 \\ Fax: +39 0412700413 \\ e-mail: elisa.calliari@feem.it
}

\section{Acknowledgements}

The author also gratefully thanks Dr. Jaroslav Mysiak, Dr. Reinhard Mechler, Dr. JoAnne Linnerooth-Bayer and Dr. Thomas Shinko for the valuable suggestions and assistance in this research. Part of the research was developed in the Young Scientists Summer Program at the International Institute for Systems Analysis, Laxenburg (Austria).

\section{Funding}

This work was supported by the European Union under the CASCADE Action (Climate change adaptation strategies for water resources and human livelihoods in the coastal zones of Small Island Developing States, Grant contract id number FED/2011/281-147) implemented by the ACP Caribbean \& Pacific Research Programme for Sustainable Development, $10^{\text {th }}$ European Development Fund, and under the Seventh Framework Program (FP7/2007-2013) ENHANCE project (Enhancing risk management partnerships for catastrophic natural disasters in Europe, Grant Agreement 308438). 


\section{Loss \& Damage: a Critical Discourse Analysis of Parties' Positions in Climate Change Negotiations}

The years-long negotiations on loss and damage (L\&D) associated with climate change impacts reached a milestone with the adoption of the Paris Agreement, sanctioning the permanence of the Warsaw International Mechanism (WIM) created in 2013. The WIM aims at advancing knowledge gathering, coordination and support to address L\&D associated with extreme and slow onset events in vulnerable developing countries (Decision 2/CP.19). Despite being among the most controversial issues to be recently treated in climate change negotiation, $L \& D$ has attracted little attention in the field of international relations. This paper aims at addressing this gap by reconstructing the emergence and evolution of the negotiating positions on L\&D of developing and developed countries. It employs a critical discourse analytical approach and builds on Fairclough's threedimensional framework for critical discourse analysis, taking decision 2/CP.19 as the core communicative event. Consistently, the decision is analysed at three different levels: as a text (micro scale); as a discursive practice (meso scale); and as a social practice (macro scale). The analysis makes use of a wide range of materials including previous decisions, High Level Segment statements and Parties submissions. It reconstructs Parties' conflicting views on the positioning of L\&D vis-à-vis the adaptation space ( $\&$ \&D as a part of, or as beyond adaptation) and the scientific, ethical and legal arguments employed to support these standpoints. It highlights, in particular, the strategic importance which the 'compensation argument' had in determining developing countries' capacity to influence the UNFCCC process up to the inclusion of a specific article on L\&D in the Paris Agreement. While calls for compensation might have lost momentum as a result of the Warsaw and Paris talks, the paper argues that their potential is far from exhausted. They in fact imply a more general request for climate justice which the UNFCCC has not yet addressed.

Keywords: Loss and Damage; climate change negotiations; critical discourse analysis; compensation; climate justice 


\section{Introduction}

The years-long negotiations on loss and damage (L\&D) associated with climate change impacts reached a milestone during the twenty-first session of the UNFCCC Conference of the Parties (COP 21) with the inclusion of a dedicated article in the Paris Agreement. Article 8 recognizes the importance of 'averting, minimizing and addressing' $\mathrm{L} \& \mathrm{D}$, and the role of sustainable development in reducing the associated risk. It sanctions the permanence of the Warsaw International Mechanism (WIM), created in 2013 to advance knowledge gathering, coordination and support to address L\&D associated with the adverse effects of climate change, including extreme and slow onset events, in particularly vulnerable developing countries (UNFCCC 2014b). At the same time, it leaves the door open for the WIM to be 'enhanced and strengthened' through future COP decisions. The article calls on Parties to work 'on a cooperative and facilitative basis' to 'enhance understanding, action and support' in areas including early warning systems, comprehensive risk assessment and management, risk insurance facilities, climate risk pooling, and non-economic losses.

Discussion on L\&D, formally initiated with the 2007 Bali Action Plan (UNFCCC 2008) and later embedded in the Cancun Adaptation Framework (UNFCCC 2011c), has been campaigned by the Alliance of Small Island States (AOSIS) since the early 1990s. AOSIS' claims have mainly focused on the establishment of a compensation mechanism, able to indemnify the developing countries for those unavoidable impacts that materialize when both mitigation and adaptation actions have been undertaken. However, the WIM does not consider the most advanced economies accountable for past and ongoing humaninduced climate change, nor does it make any tangible commitment for helping lowincome and small developing island states to cope with L\&D.

The WIM's focus on knowledge and expertise sharing activities reflects the ongoing disagreement on the exact boundaries of the L\&D concept. The developing countries consider L\&D to be something beyond adaptation, referring to those impacts that can no longer be addressed by mitigating emissions or helping countries to adapt. On the other hand, developed countries refuse the idea that L\&D is something qualitatively different from adaptation, and contain the concept within its scope. This dispute seems far from settled. At the UNFCCC level no formal discussion has yet been undertaken on what L\&D could signify. A mere working definition has been adopted, vaguely describing $L \& D$ as 'the actual and/or potential manifestation of impacts associated with climate change in developing countries that negatively affect human and natural systems' (UNFCCC 2012d). The definition distinguishes losses from damages on the basis of the 'irreversibility' of the negative impacts, where the former are those for which restoration is impossible and the latter those that can instead be repaired. Emphasis is also placed on the difficulties in evaluating $L \& D$ from an economic point of view, given the challenges in attaching monetary values to important factors such as life, culture, livelihood, territory and statehood, among others.

The issue of L\&D has attracted increasing attention among the climate change 
academic community, although being almost disregarded in the field of international relations. Efforts have been made to provide historical overviews on the emergence of L\&D in international talks, to analyse the role of the UNFCCC in addressing it, and to discuss the possible implications of the WIM (McNamara 2014; Huq, Roberts, and Fenton 2013; Roberts and Huq 2015; Stabinsky and Hoffmaister 2015; Mathew and Akter 2015); to frame it through a disaster risk management and reduction perspective (Fekete and Sakdapolrak 2014; Birkmann and Welle 2015; Mechler et al. 2014); to outline the main contributions attribution studies could offer to the assessment of L\&D (James et al. 2014; Huggel et al. 2013); to show its connection with the concept of state responsibility (Verheyen 2015; Tol and Verheyen 2004; Verheyen 2012; Mayer 2014). Some authors (Warner \& van der Geest, 2013, 2015) have taken a promising look at the connection between L\&D and the constraints and limits to adaptation literature (Dow et al. 2013; IPCC 2014; Adger et al. 2009), breaking as yet unexplored ground for future research.

Despite this growing academic interest, the main conceptual and operational issues around L\&D remain widely debated (Wrathall et al., 2015). Important questions include the qualification of $L \& D$ as a different category within climate change impacts and the consequent need for it to be addressed with an ad hoc instrument. Arguably, the sole circumstance of its materialising in particularly vulnerable developing countries, as mentioned in the working definition as well as in the Warsaw Decision, seems a necessary but not sufficient condition. Framing $L \& D$ as the actual or expected climate change impacts which exceed the scope of adaptation might provide a better ground for qualifying them. Yet, positioning L\&D vis-a-vis the adaptation space is indeed problematic. Should only the social, technical and physically hard limits to adaptation be considered in defining L\&D? Or should the financial, institutional, cultural, behavioural constraints that could in principle be overcome but that in fact prevent effective adaptation actions to take place also be considered? Should the latter hold true, distinguishing action on L\&D from other adaptation -but also development and disaster risk reduction- strategies would become ultimately difficult. While it might exceed the scope of this paper to examine these definitional issues, it interestingly explore how the related conceptual uncertainties and ambiguities have translated at the negotiations level. In particular, this paper aims at reconstructing the emergence and interaction of different discourses, i.e. forms of understanding and representing L\&D, under the UNFCCC and the way they eventually shaped both the structure and the content of the WIM. To do so, it employs a Critical Discourse Analysis (CDA) as a strategy not only for interpreting but also for explaining discourse structures (Fairclough and Wodak 1997). The choice of CDA is also instrumental for gaining insights into the unfolding of power relations among Parties on $L \& D$, given the interest of critical studies on the relationship between power and language. In particular, CDA particularly focuses on the ways discourse structures enact, confirm, legitimate, reproduce, or challenge relations of power and dominance in society (van Dijk 2001).

Hence, the paper contributes to the existing literature on L\&D in three ways: (1) by providing a systematic analysis of how discourses on L\&D have emerged and evolved 
within climate negotiations; (2) by highlighting the main elements impeding a common framing of (and thus action on) the issue; (3) by offering insights into the negotiating strategy on L\&D of the developing countries' and their capacity to influence the UNFCCC process. It is organised as follows. The first section provides an overview of the theory and method of discourse analysis: particular attention in given to the CDA approach and its theorization by Norman Fairclough. The subsequent analysis applies Fairclough's three-dimensional model for CDA to Decision 2/CP.19 establishing the WIM. The latter was chosen as the core communicative event, for it represents a fundamental milestone in the $\mathrm{L} \& \mathrm{D}$ discussion under the UNFCCC. The Decision is analysed in connection with other official UNFCCC documents, which include previous COP decisions (1/CP.16, 7/CP.17, 3/CP.18), High Level Segment statements made by Heads of States and Governments at COP 19/CMP 9, and Parties' submissions to the Subsidiary Body for Implementation (SBI), the Subsidiary Body for Scientific and Technological Advice (SBSTA), and the Ad Hoc Working Group on the Durban Platform for Enhanced Action (ADP). The findings are discussed in the light of the negotiation process leading to the inclusion of Article 8 on L\&D in the Paris Agreement. The main sources of discord are identified in Parties' positioning of L\&D vis-à-vis the adaptation space (L\&D as a part of or as beyond adaptation) and in the ethical (fairness concerns and non-economic L\&D), scientific (issues of attribution) and legal (State Responsibility for wrongful acts) arguments employed to support these standpoints. Particular attention is placed on analysing the strategic importance the State Responsibility-compensation argument had in determining the capacity of the developing countries to influence the UNFCCC process. Although after Paris compensation may no longer be the elephant in the room, the discourse analysis suggests a potential for it to re-emerge. Disputes of this type are symptoms of a more general need for climate equity and justice that the UNFCCC has not yet addressed.

\section{Methods and materials}

Although there is no generally accepted definition of discourse in social science (Pedersen 2009), it might be generally interpreted as a particular way of talking about and understanding the world, or one aspect of the world (Jorgensen and Phillips 2002). Discourse analysis is a strategy for revealing how the understanding of the world is built through language and how, conversely, language contributes to changing social reality. It draws attention to the way discourse is produced, what it excludes, the way some kinds of knowledge become significant while other do not, and the way power relations are reflected in language (Friman 2013; Hesse-Biber and Leavy 2011).

Discourse Analysis is rooted in a social constructionist approach within social sciences and humanities (Pedersen 2009). Despite the common epistemological premises, a number of approaches can be found that differ inter alia with respect to the role of discourse in the construction of the world and the analytical focus (van Dijk 2001). Among them, CDA is primarily concerned with 'the connections/relationships between 
language use, its producers and consumers, and the social and political contexts, structures, and practices in which it occurs' (Waugh et al. 2015). In this sense, the notion of context is crucial for CDA (Meyer 2001), with discourses being understood as historically produced and interpreted, as well as structured by existing power relations and ideologies. Given the relevance of extralinguistic factors such as culture, society, and ideology (Meyer 2001), CDA calls for a wide range of analytical tools to be employed and a transdisciplinary approach to be followed (Fairclough 2003).

In critical discourse studies particular relevance is given to the relation between language and power (Wodak 2001). Consistently, they focus on the ways discourse structures enact, confirm, legitimate, reproduce, or challenge relations of power and dominance in society (van Dijk 2001). Attention is given to social problems and political issues, in an attempt not only to interpret but also to explain discourse structures (Fairclough and Wodak 1997). Investigating power relations in society helps to reveal inequalities and thus to contribute to social change. In this sense the analysis is meant to be critical. As negotiations under the UNFCCC are characterized by marked power asymmetries, CDA turns out to be useful for detecting whether such asymmetries were reflected in L\&D discussions. Although CDA theory and methodologies are commonly employed in IR research (Farrands, El-Anis, and Pettiford 2015), their application to the context of climate change negotiations is still at an early stage (see, for instance Friman, 2007, on historical responsibility in climate talks).

Among CDA approaches, the paper builds upon Norman Fairclough's theoretical contribution to critical discourse studies for his emphasis on the empirical and systematic analysis of language use in social interactions. A central idea in his work is that discourse is not only constitutive, but also constituted (Fairclough 1992). Therefore, a two-way relation is established: discourse is a social practice that reproduces and changes knowledge but at the same time it is also shaped by social practices and structures. Thus, contrarily to other approaches to discourse analysis, his keeps a distinction between discursive and non-discursive practices. Discourses include texts, talks and other semiological systems, while there are other practices (economy, for instance) that follow different logics and need to be studied with different analytical tools. For the analysis of COP Decision 2/CP.19, the paper adopts his three-dimensional model for CDA (Fairclough 1992). The starting point is the consideration of two important elements of the discourse: (1) the communicative event (e.g., a text or a speech); (2) the order of discourse, i.e. the configuration of all discourse types used in a specific field. The communicative event has three dimensions, each of which is to be covered by a specific analysis:

(1) it is a text, and should be subject to a linguistic analysis including vocabulary, grammar, syntax (micro scale analysis);

(2) it is a discursive practice: attention should be given to how the text is produced and consumed, focusing on the way power relations are enacted. The underlying hegemonic processes, through which consensus around meanings emerges, 
should be explored (meso scale analysis);

(3) it is a social practice, which implies consideration of how the discursive practices reproduce or restructure the existing order of discourse and how this translates into social change (macro scale analysis).

The analysis of COP Decision 2/CP.19 (communicative event) in section 3 is carried out according to these three dimensions, although not in the order described above. This is because Fairclough's model offers multiple entry points for analysis: the scale chosen for beginning with is not relevant as long as all the three scales are analysed and their mutual interconnection is shown (Janks 1997). Consistently, section 3 starts with the analysis of the discursive practice (meso scale) in order to provide the reader with an overview of the particular discourses employed by Parties up to the Warsaw Conference.

The text of 2/CP.19 constitutes the core of the analysis and is examined in connection with other relevant documents, including previous COP decisions (1/CP 16, 7/CP 17, 3/CP 18), High Level Segment statements made by Heads of States and Governments at COP 19/CMP 9 ( $n=133)$, Parties' submissions to the SBI, SBSTA and ADP ( $n=33)$, press releases and other relevant documents available at the UNFCCC website. Table 1 (Primary and secondary sources used for carrying out the CDA) shows the materials employed at the different scales of the analysis. The use of such a wide range of materials was functional to reconstructing in an organic way the different discourses adopted by Parties on L\&D from the early 1990s onwards. 


\begin{tabular}{|c|c|c|c|}
\hline & Type of document & Title & Notes \\
\hline 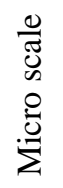 & COP Decision & $\begin{array}{l}\text { Decision 2/ CP 19.Warsaw international mechanism for loss and damage associated with climate change } \\
\text { impacts (UNFCCC 2014b) } \\
\text { Warsaw international mechanism for loss and damage associated with climate change impacts. Proposal } \\
\text { by the President. Draft COP decision -/CP.19, (UNFCCC 2013d) }\end{array}$ & \\
\hline \multirow{7}{*}{ 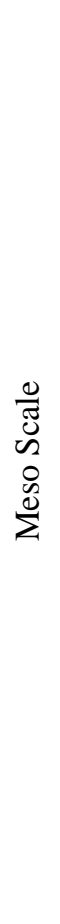 } & COP Decision & $\begin{array}{l}\text { Decision 1/CP 16. The Cancun Agreements: Outcome of the work of the Ad Hoc Working Group on } \\
\text { Long-term Cooperative Action under the Convention (UNFCCC 2011c); } \\
\text { Decision 7/CP 17. Work programme on loss and damage (UNFCCC 2012e); } \\
\text { Decision 3/CP 18. Approaches to address loss and damage associated with climate change impacts in } \\
\text { developing countries that are particularly vulnerable to the adverse effects of climate change to enhance } \\
\text { adaptive capacity(UNFCCC 2013c). }\end{array}$ & \\
\hline & $\begin{array}{l}\text { High Level Segment statements } \\
\text { by Heads of States and } \\
\text { Governments }\end{array}$ & $\begin{array}{l}\text { High Level Segment statements by Heads of States and Governments at COP 19/CMP } 9 \text { (UNFCCC } \\
\text { 2013b) }\end{array}$ & $\begin{array}{l}\text { Number of individual } \\
\text { submissions: } 113^{1}\end{array}$ \\
\hline & \multirow{5}{*}{$\begin{array}{l}\text { Submissions by parties and } \\
\text { organizations to the SBI }\end{array}$} & $\begin{array}{l}\text { Views and information on elements to be included in the work programme on loss and damage. } \\
\text { Submissions from Parties and relevant organizations.(UNFCCC 2011a) }\end{array}$ & $\begin{array}{l}\text { Number of individual } \\
\text { submissions: } 22\end{array}$ \\
\hline & & $\begin{array}{l}\text { Views and information on the thematic areas in the implementation of the work programme (UNFCCC } \\
\text { 2011b) }\end{array}$ & $\begin{array}{l}\text { Number of individual } \\
\text { submissions: } 7\end{array}$ \\
\hline & & $\begin{array}{l}\text { Views and information from Parties and relevant organizations on the possible elements to be included in } \\
\text { the recommendations on loss and damage in accordance with decision 1/CP.16 (UNFCCC 2012a) }\end{array}$ & $\begin{array}{l}\text { Number of individual } \\
\text { submissions: } 3\end{array}$ \\
\hline & & $\begin{array}{l}\text { Views and information from Parties and relevant organizations on the possible elements to be included in } \\
\text { the recommendations on loss and damage in accordance with decision 1/CP.16. Add.1(UNFCCC 2012b) }\end{array}$ & $\begin{array}{l}\text { Number of individual } \\
\text { submissions: } 13\end{array}$ \\
\hline & & $\begin{array}{l}\text { Views and information from Parties and relevant organizations on the possible elements to be included in } \\
\text { the recommendations on loss and damage in accordance with decision 1/CP.16. Add. } 2 \text { (UNFCCC 2012e) }\end{array}$ & $\begin{array}{l}\text { Number of individual } \\
\text { submissions: } 2\end{array}$ \\
\hline
\end{tabular}

${ }^{1}$ Submissions by Egypt, Iraq, Jordan, Kirgizstan, Libya, Morocco, Qatar, Sudan, Syrian Arab Republic, Tunisia, Belarus, Tajikistan, United Arab Emirates were not analysed because of linguistic reasons. 


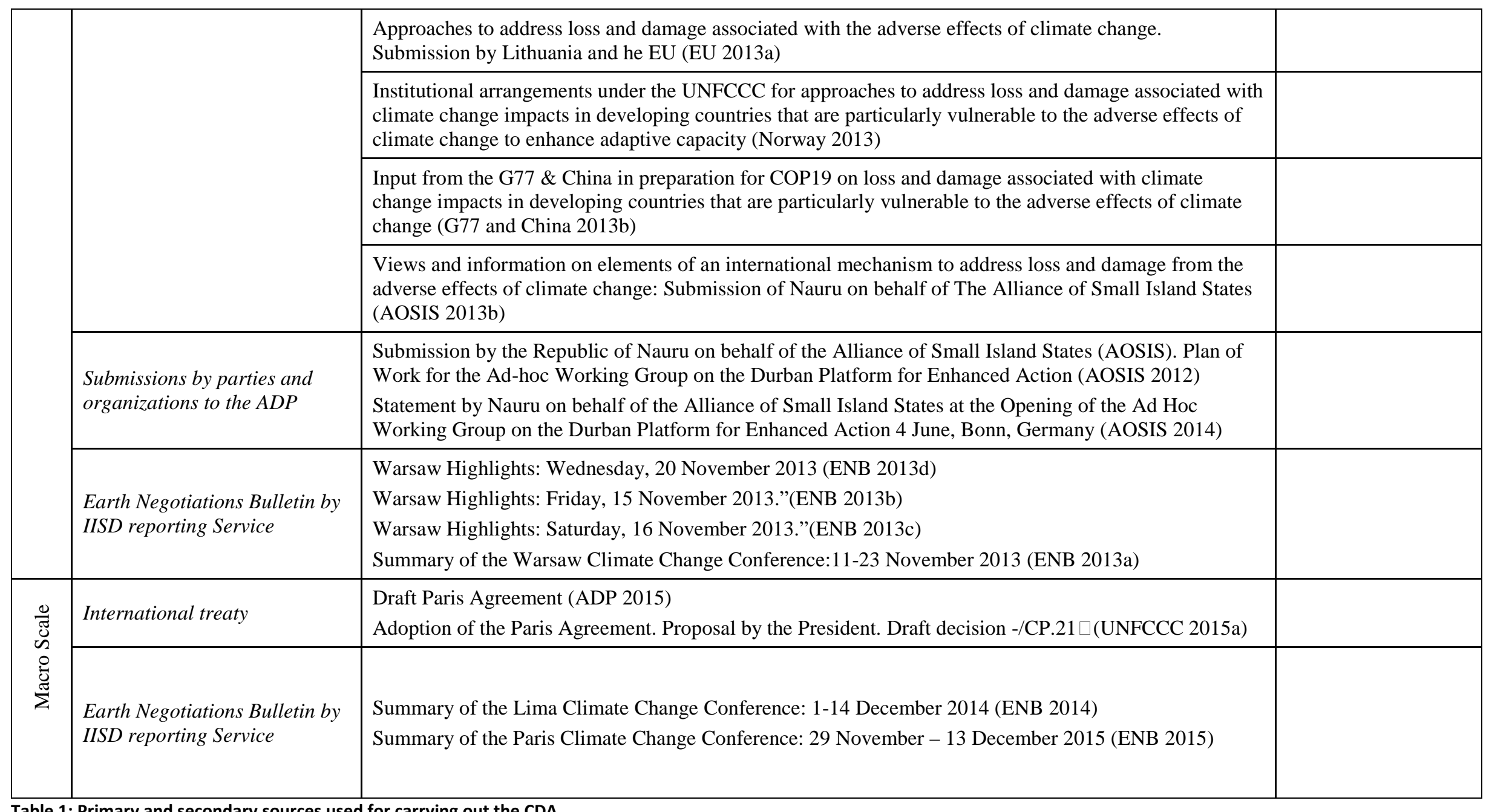

Table 1: Primary and secondary sources used for carrying out the CDA 


\section{Critical Discourse Analysis of the Warsaw decision (2/CP.19)}

\section{Meso scale analysis}

The analysis of the discursive practice (meso scale in Fairclough's model) is here taken as a starting point for understanding how the 'authors' of Decision 2/CP.19 (i.e. negotiators) drew on existing discourses when producing the text. It entails (a) eliciting the particular ways in which the authors understand and represent the issue, and (b) detecting how such views interacted. This section first systematises the Parties' positions on L\&D building on the submissions and statements delivered up to the Warsaw Conference. It then traces their emergence and interplay within the UNFCCC, focusing in particular on the negotiation dynamics during COP19.

\section{Discourses on L\&D under the UNFCCC}

As already recalled, developing and developed countries frame L\&D in two conflicting ways, the former claiming $L \& D$ to be something beyond adaptation and thus requiring additional and distinct instruments, and the latter including L\&D within the scope of adaptation. These opposite views were embedded in several submissions and statements by Parties to the SBI between 2011 and 2012. For instance, Gambia referred to L\&D as those 'impacts that cannot be avoided by mitigation and can go beyond and exceed LDCs adaptive capacity'(UNFCCC 2011b). Bolivia (Plurinational State of), Ecuador, China, El Salvador, Guatemala, Thailand, Philippines and Nicaragua followed suit by defining L\&D as being “ "beyond adaptation”, (...) additional to adaptation, focusing on challenges of both identifying and addressing the instances when adaptation is no longer possible'. The position was also echoed by Ghana, Gambia on behalf of LDCs (UNFCCC 2012b) and by Swaziland on behalf of African states (UNFCCC 2012c). AOSIS, at the SBI Opening Plenary in Warsaw, reiterated the concept by qualifying L\&D as 'something else entirely' from mitigation and adaptation (AOSIS 2013). This conceptualization of L\&D as a third pillar of climate action has been based on the existence of tipping points in socio-ecological systems - see for instance Bolivia and Gambia in their submissions to SBI 37 (UNFCCC 2012b)-, as well as barriers in the capacity to adapt (UNFCCC 2011b) and respond (AOSIS 2013). As for the impacts considered, statements by developing countries focus on current or expected adverse effects of climate change that are in principle quantifiable and monetizable. These include, for instance, physical impacts -e.g. loss of land because of sea level rise - and economic impacts, as in the case of the loss of development opportunities advanced by Bolivia (UNFCCC 2012b). Consistently, the remedies sought are pragmatic in nature. They point to the establishment of insurance tools to contrast the financial risk posed by extremes as well as the creation of compensation/rehabilitation/solidarity funds. Financial support for disaster risk reduction activities has also been identified as a key factor for avoiding or reducing the potential for L\&D to materialise. 
Calls for compensation, in particular, have been advanced by AOSIS since the early 1990s. During the very negotiations of the UNFCCC, the group proposed the establishment of an international insurance scheme to be funded by mandatory contributions from industrialised parties on the basis of their Gross National Product (GNP) and relative GHG emissions. The scheme was to compensate small island and low-lying developing nations for loss and damage resulting from sea level rise (SLR) (Linnerooth-bayer, Mace, and Verheyen 2003; AOSIS 2008). Traces of this proposal can still be found in article 4.8 of the 1991 Convention, where it calls on parties to consider appropriate actions 'including (...) funding, insurance and the transfer of technology' (Linnerooth-bayer, Mace, and Mechler 2013). The idea was advanced again in 2008 and 2012, in the form of a MultiWindow Mechanism to Address Loss and Damage from Climate Change Impacts in SIDS and other developing countries particularly vulnerable to the impacts of climate change (AOSIS 2008). The mechanism comprised three interdependent components: (1) an Insurance Component; (2) a Rehabilitation/Compensatory Component; (3) a Risk Management Component. The Compensatory component was deemed necessary to address the residual L\&D resulting from slow onset events, 'such as sea level rise, increasing land and sea surface temperatures, and ocean acidification'. Interestingly, the proposal cites State Responsibility among its guiding principles, together with the Polluter Pays Principle, common but differentiated responsibilities and respective capabilities (CBDR-RC), precautionary principle, principles of equity and intergenerational equity, and international solidarity. The reference to State Responsibility is of particular interest here as inextricably linked to the concept of compensation. The latter is indeed a type of reparation envisaged in the case of State Responsibility for wrongful acts. Although debated, some authors (Tol and Verheyen 2004) believe it is possible to hold a state generally responsible for climate change damages for breaching the no harm rule under international customary law. This same argument has been often employed by developing Parties, although it caused some discomfort among industrialised ones (Warner and Zakieldeen 2011). Besides the AOSIS grouping, calls for compensation have been advanced by Sri Lanka (UNFCCC 2011a), Bolivia (Plurinational State of), Ecuador, China, El Salvador, Guatemala, Thailand, Philippines and Nicaragua (UNFCCC 2012a), Swaziland on behalf of African states (UNFCCC 2012b), and have culminated in a joint proposal by G77 and China for a L\&D mechanism comprising 'means of rehabilitation and/or compensation' (G77 and China 2013).

On the other hand, developed countries have mostly avoided any references to compensation, and have tried instead to shift the attention to non-economic L\&D, such as 'losses of lives and negative impacts for health', and 'loss of biodiversity and ecosystem services necessary to sustain livelihoods' (Norway 2013). The U.S. also raised ethical concerns, by claiming that an 'international mechanism that includes insurance and compensation/ rehabilitation pillars would have to put a monetary value on the lives, livelihoods and assets of the most vulnerable countries and populations (UNFCCC 2012b). Consistently, they sought to move the L\&D discourse under the less contested and binding disaster risk reduction framework (Verheyen 2012). For instance, the EU 
stated that 'comprehensively addressing loss and damage surpasses the remit of the UNFCCC' and called for 'strengthen[ing] synergies with the humanitarian and disaster risk community'. The appropriateness of the DRR policy arena was justified by the US in that it was impossible to attribute 'the incidence of loss and damage to climate change, as opposed to natural climate variability and/or vulnerabilities stemming from nonclimatic stresses and trends like deforestation and development patterns' (UNFCCC 2012b). Such an attempt to shift the cause of L\&D to domestic factors was highly criticised by the developing countries (UNFCCC 2012b; UNFCCC 2012a), which emphasised how 'damage and loss can be exacerbated due to underlying vulnerabilities' but that vulnerability and risk drivers could not be seen as the cause of climate change, as manifested through changes in extremes and slow onset events.

As for the conceptualization of L\&D, developed countries have hardly engaged in definitional issues within their official submissions. Norway glibly underlined how 'approaches to reduce the risk of loss and damage are (...) an integrated part of mitigation and adaptation efforts (UNFCCC 2012a). Along the same lines, the EU stated that 'addressing loss and damage should be seen in the context of mitigation and adaptation and not as a separate issue' (UNFCCC 2012b). The US, while opposing the creation of a dedicated mechanism, called on the Convention to enhance 'adaptation action (...) in order to reduce the risk of loss and damage (UNFCCC 2012b). In general, they have opposed the establishment of a third pillar besides adaptation and mitigation, claiming that it would have just added complexity to the already intricate institutional structure of the UNFCCC (see for instance, Norway 2013).

Interaction of discourses up to COP 19

The establishment of the WIM is the result of a long process only culminating in Warsaw, through which the developing countries -and AOSIS in particular- were progressively able to influence the UNFCCC. The proactive role of AOSIS within climate change negotiations has been widely recognised and explained through its capacity for borrowing power (Betzold 2010) in a context of asymmetric negotiations (Zartman and Rubin 2002). In the specific case of L\&D, AOSIS was able to gain the support of the developing countries as a whole, as confirmed by the submissions on L\&D forwarded by the groupings of several developing countries and, most importantly by the G77/China. AOSIS could also count on the support of environmental NGOs both directly - in terms of technical and scientific expertise (Betzold 2010) and indirectly - in the form of a general endorsement of their positions (ActionAid/Care/WWF 2012; ActionAid/Care/WWF 2013; ActionAid 2010; ActionAid/Care/WWF/Germanwatch 2012) and in the active campaigning made before and during COPs. Arguably, most of the results were obtained by resorting to 'context based strategies', i.e. referring to principles and norms. In particular, the recourse to widely accepted principles of international law, such as those referred to in the MultiWindow Proposal (AOSIS 2008), contributed to reinforce AOSIS' negotiating power (Hafner-Burton, Victor, and Lupu 2012). Moreover, the well-established argument of insular states being the least 
responsible for climate change but the most adversely impacted by it, added to the moral legitimacy of AOSIS' claims beside the legal one. Taken together, these strategies led the issue of L\&D -as framed by the developing world- to gain increasing visibility within climate change talks and to get the support of practitioners and academics. On the other hand, developed countries mostly opted for defensive strategies, trying to neutralise the L\&D discourse through recourse to disaster risk reduction and standard narratives of climate change adaptation.

Despite such increased negotiating power, the developing countries had a hard time in pursuing their interests at COP 19. This is shown by the analysis of the High Level Segment statements by Heads of States and Governments as well as the IISD reporting services coverage of the Warsaw Climate Change Conference. L\&D was one of the major outcomes to be expected from the Warsaw meeting. Yet, Parties endorsed this agenda item with a differentiated sense of urgency. Among the 113 High Level Segment Statements analysed, the establishment of the mechanism was referred to in 52 of them, among which only 4 were put forward by developed countries. Among them, the EU (2013) and Ireland (2013) called for progress on, inter alia, the L\&D mechanism. On the contrary, the statements by Russia (Russian Federation 2013) and by the Umbrella Group (2013), while recognizing the importance of adaptation for the most vulnerable countries, stressed that 'drawing on existing arrangements provides the best means to address loss and damage'.

These diverging views were only the prelude to a complex negotiating process. Difficulties in agreeing on the mechanism within the SBI resulted in several manifestations of impatience among negotiators, with the Philippines expressing 'deep concern' over the lack of progress on L\&D together with Fiji for G77/China, Nauru for AOSIS, and Nepal for LCDs (ENB 2013b). Without significant progress on the issue, the SBI adopted its conclusions (UNFCCC 2013a) forwarding them to the COP for further consideration (ENB 2013c). The blockage continued within the high level segment of the COP, where some developing countries expressed disappointment over the developed countries' lack of commitment (ENB 2013d). The COP President requested ministerial support to continue consultations: the outcome was then presented to the COP for adoption (UNFCCC 2013a). The text (Decision 2/CP.19) was finally adopted, as orally amended in the plenary, after a long debate about the provision placing the mechanism under the Cancun Adaptation Framework (ENB 2013a).

\section{Micro Scale analysis}

A comparison between the text of the Draft COP decision proposed by the President (UNFCCC 2013b) and the text that was finally adopted -Decision 2/CP.19 (UNFCCC 2014a)- illustrates the points on which compromise was reached. Coupled with the linguistic analysis (micro scale in Fairclough's model), it also reveals the knots in the conceptualisation of $L \& D$ that Parties were not able to untie. Three main formulations were added to the draft proposal by the President in order to reach a final resolution: 
(1) 'Also acknowledging that loss and damage associated with the adverse effects of climate change includes, and in some cases involves more than, that which can be reduced by adaptation,' (preamble);

(2) 'subject to review at the twenty-second session of the Conference of the Parties (November-December 2016) pursuant to paragraph 15 below,' (\$1 of the Decision);

(3) 'including its structure, mandate and effectiveness,' (\$15 of the Decision)

The first formulation was introduced to accommodate the opposite understandings by the developed and developing countries on L\&D. A systematic reading of 2/CP.19 reveals that the text defines the relationship between $L \& D$ and adaptation in two opposing ways. According to line 6 of the Decision, L\&D 'includes, and in some cases involves more than, that which can be reduced by adaptation', while at line 13 the WIM is placed 'under the Cancun Adaptation Framework'. The first statement recognizes L\&D as something which, in some cases, can go beyond adaptation and thus recognizes the claims of the developing countries. On the contrary, the second statement -placing L\&D under the Cancun Adaptation Framework- suggests a relationship of subordination between the concepts, with L\&D being a part of adaptation as argued by the developed countries. This is a case of 'constructive ambiguity', a tool often used in diplomacy to surmont situations of impasse (Berridge and James 2001). It is employed when parties have strong and contradictory interests and views and/or the negotiations are running short of time (Pehar 2011).

The incapacity to agree on a shared definition on L\&D is also shown by the insertion of the second and the third formulations, requiring a review of the mechanism 'including its structure, mandate and effectiveness' at COP 22 in 2016. Arguably, the requirement was included following the request by the developing parties' to leave the door open for L\&D to be separated from adaptation during the 2016 revision.

Another interesting consideration can be made on the basis of the linguistic analysis and deals with the issue of climate change attribution. In Decision 2/CP.19 and in those adopted since Bali, L\&D is referred to as being associated with climate change impacts, including extreme weather events and slow onset events. This might represent another case of constructive ambiguity in its lexical form. The verb 'associate' implies a connection between two things either because they occur together or because one produces the other (Stevenson 2011). Thus, the verb can entail different relationships linking the concepts: they can be on the same level, being simply connected, or one can be subordinated to the other, as caused by the latter. Additional research should be done to understand why this specific expression has been used in the negotiations process. It could possibly signal a compromise among Parties on the legitimacy of L\&D to be discussed within the climate change arena. Indeed, the term is broad enough to include the possibility for L\&D to be treated under the UNFCCC, without explicitly and formally recognizing any strict causal link with climate change impacts. This would be consistent, 
for instance, with the claims by some developed countries that it is impossible to disentangle domestic issues of vulnerability and exposure when accounting for L\&D. Alternatively, the expression could simply refer to the current uncertainty in attributing extreme events to anthropogenic climate change (IPCC 2012; IPCC 2013), where it is still problematic for very rare weather events to gain enough statistical power to detect a trend (Huggel et al. 2013).

The issue of attribution is of the outermost importance when talking about compensation as the causal link between the damage and the act/omission is a necessary condition for ascribing responsibility to a State. However, it might not always be possible to prove the causal link between GHG emissions and meteorological change and to establish a link between the latter and related adverse impacts. Distinguishing the contribution and the signs of other factors, especially exposure and vulnerability, to L\&D is equally complex. In the absence of such causal links, it becomes difficult in the end to make claims for compensations. Yet it is interesting to note how these uncertainties are often linguistically put aside by the developing countries. Arguably, the attempt is to avoid confronting the possibility that the lack of robust scientific evidence might imply (and more importantly, might be used) to delay action. An example is provided by Nauru's submission to COP 19 where the alleged causal link between L\&D and climate change impacts is made explicit by the very title: 'Views and information on elements of an international mechanism to address loss and damage from the adverse effects of climate change' (AOSIS 2013), where the preposition 'from' semantically indicates the source or cause of something (Stevenson 2011).

\section{Macro scale analysis}

Moving now to the macro scale in Fairclough's model, we can draw attention to the question of whether the existing order of discourse on L\&D has been transformed by discursive practices at COP 19 negotiations. Undoubtedly, the developing countries were able to introduce and institutionalise a 'new' discourse on L\&D in the final text of Decision 2/CP.19 in referring to it as something beyond adaptation. This was important not only from a conceptual point of view, but also to give dignity and strength to the claimed need for the elaboration of different and additional means to address L\&D beside adaptation. Nevertheless, the way in which the developing countries conceptualised L\&D was not fully endorsed by other Parties - at least, not up to the Paris climate change conference. What reasonably happened in Warsaw was that developed countries 'learned' this new discourse for the purpose of closing the negotiation process, but at the same time they refrained from internalizing it. Indeed, new discourses may come into an institution without being enacted or inculcated (i.e. owned by subjects), or they may be enacted but never fully inculcated (Fairclough 2003).

This impression is reinforced by the way L\&D was dealt with during the subsequent negotiation rounds. One could recall, for instance, the hard time AOSIS had in inserting a mere reference to L\&D and the WIM in the preamble of the Lima Call for Climate action at COP 20 (ENB 2014). Lively exchanges of views also characterised 
discussions under the ADP with regard to the inclusion of L\&D in the Paris Agreement. While the developing countries were advocating the insertion of a dedicated article on L\&D, calling for it to be 'a central element of the Paris agreement', and treated as 'separate and distinct' from adaptation, the developed countries campaigned against including any reference in the final text. The proposal by the US, Canada, Switzerland, Norway, Japan, and New Zealand with the general support of the EU, while suggesting the permanence of the WIM after 2020, offered to address L\&D by means of COP decisions (ADP 2015), a tool whose legal binding nature is highly debated (Beyerlin and Marauhn 2011). As a response, the G/77 and China raised the stakes by advancing the establishment of a new mechanism under the agreement which was to replace the WIM and feature a climate displacement coordination facility 'to address the displacement of people as a result of extreme impacts of climate change' (ADP 2015). During COP 21 itself, negotiations on L\&D proved to be contentious from the very start and it took an entire week to get the first formal advancement on the issue. It was only with the release of the first Draft of the Agreement on November 5th that two options for L\&D to appear in the final text were included: as a separate article or as a part of the adaptation provisions (UNFCCC 2015b).

It is true that the developing countries eventually managed to get a stand-alone article on $L \& D$, formally crystallising the idea of its being something distinct from adaptation. In this sense they scored a historic victory. Yet the discussions recalled above show the fragility of the consensus reached from Warsaw onwards and eventually cast doubts on the very results obtained in Paris. L\&D looks like a foreign body within the Agreement architecture, as no reference is made to Article 8 by other treaty provisions. It is not mentioned in the purpose of the Agreement (Article 2), in the context of the 'ambitious efforts' required to achieve it (Article 3), in the related transparency framework (Article 13), or in the global stocktake process (Article 14). This signals not only the 'last minute' nature of the agreement reached at COP 21, but also -and most importantly- the contested status that $L \& D$ continues to have under the UNFCCC. Besides the symbolic meaning of keeping L\&D separate from adaptation, Article 8 contains tentative, cautious language, calling again for an explorative rather than an operative mandate. Overall, the attempt by the developing countries to transform the order of discourse by elevating $L \& D$ to a third pillar of climate action, subsequent to the 'preventive' phase of mitigation and the 'managing' phase of adaptation (CDKN 2012), seems to have been only partially achieved.

\section{Discussion}

The CDA carried out in the previous section made it possible to reconstruct the emergence and the evolution of discourses on L\&D under the UNFCCC, by showing how their interaction eventually resulted in the establishment of the WIM. It illustrated the conflicting views of Parties on the positioning of L\&D vis-à-vis the adaptation space (L\&D as part of or as beyond adaptation) as well as the narratives employed to support these standpoints. As a whole, the developed countries' discursive practice aimed at 
neutralising the conceptualization of $L \& D$ as a new pillar of climate action by shifting its focus towards the alternative (and less contested) humanitarian and disaster risk policy frameworks. Science was also used to delegitimise compensation claims, by stressing the impossibility of distinguishing the contribution of climate change to L\&D from other factors, such as natural climate variability or existing patterns of vulnerability and exposure. Finally, ethical claims were also made to avoid the 'monetisation' of the discourse, by hinting at the inappropriateness of placing price-tags on the lives, livelihoods and assets of the most vulnerable countries and populations.

The ethical imperative raised by the developing countries was substantially different. It pointed instead to the unfairness of climate change (affecting first those least responsible for the problem) and to the threats for survival it posed for the most exposed communities. The legal counterpart of the ethical imperative, i.e. the State Responsibilitycompensation argument, equally became a leitmotiv in the conceptualization of L\&D by the developing countries. However, as the analysis of statements and submissions shows, its employment might have lost momentum in climate talks. It surely represented a cornerstone in the requests by the developing countries up to the Warsaw conference in 2013. It was indeed the main request embedded in the 1991 insurance scheme proposal for addressing the impacts deriving from SLR. The 2008 MultiWindow Proposal widened the range of the hazards considered by including extremes, and consistently called for an insurance component to manage the associated financial risks. Yet the compensatory component continued to stand out and be campaigned as the sole way to address the unavoidable impacts resulting from slow onset events. This standpoint was maintained not only by AOSIS, but also by the groupings of other developing countries (e.g. the Bolivarian Alliance for the Peoples of Our America - ALBA) and even most importantly, by the $\mathrm{G} 77$ as a whole. After Warsaw, however, calls for compensation have become episodic. Briefly after the conclusion of COP 19, the developing countries' negotiators on L\&D downplayed the importance of financial compensation, stating that it 'may represent a normative solution to the perils of vulnerable countries, but does not necessarily mean that the underlying needs are addressed' (Hoffmaister et al. 2014). An analysis of recent submissions by Parties indicates little recourse to the concept. As an interesting exception, an early 2015 draft of the Paris agreement mentioned 'compensation measures for people displaced by climate change' among the functions to be performed by the proposed Climate Change Displacement Coordination Facility (Wentz and Burger 2015). The provision was nevertheless dropped - without excessive clamour- in subsequent talks.

The parabola of the 'compensation argument' suggests a progressive transformation of this concept from being an 'end' to being a 'mean'. It could be argued that rather than being an objective per se, compensation has been used by AOSIS as a bogeyman to increasingly get concessions on L\&D from the developed countries. Such a strategic use of the concept may not have characterised the positions small islands from the beginning but may have appeared at a later stage, when it became clear that the lack of legitimation of the L\&D issue under the UNFCCC would eventually prevent any 
meaningful advancement on the issue. Hence, calls for compensations may have been used strategically to obtain the institutionalisation of the L\&D discourse under the UNFCCC, first through the WIM and then through its crystallisation by article 8 of the Paris Agreement. In this perspective, the establishment of the mechanism may have had more a symbolic rather than a practical significance. The impression is reinforced by the outcome of COP 21, where Parties eventually confirmed an explorative rather than an operational mandate for the WIM.

The limited recourse to the State Responsibility-compensation argument can also be explained by a progressive loss of appeal due to the difficulties in its activation. In fact, the applicability of a legal remedy to L\&D is arguable, especially when considering issues of attribution of extremes to anthropogenic climate change. Another emerging concept such as state liability, i.e. responsibility for acts not prohibited by international law, has been proposed as a better framework for the issue (Hyvarinen 2012) ${ }^{2}$. There are however two drawbacks in the employment of the state liability argument. The first concerns its viability as a legal option: the concept is still rudimentary within International Law and the possibility to employ it as a general principle of customary law is disputable. So far it has been envisaged only by the Convention on International Liability for Damage Caused by Space Objects (1972). The second issue touches upon the political opportuneness of using such an argument. Although not referring to fault -no international obligation has to be breached-, liability would inevitably imply compensation and again cause discomfort among Parties.

With calls for compensatory justice being put aside, it would be tempting to think that the underlying requests and needs of the developing countries have been eventually satisfied, though this is probably not the case. L\&D continues to be a particularly thorny matter because it is inherently connected to other controversial and unresolved discourses under the UNFCCC: those of historical responsibility and differentiation. Talking about historical responsibility means recognising that past GHG emissions should be taken in consideration when deciding who has caused the present situation and who should therefore take on a larger responsibility in addressing the problem (Friman 2007). Moreover, when coupled with the concept of differentiation, historical responsibility has become the rationale for and the way to concretely operationalising equity (Friman and Hjerpe 2015). Yet a consensus on how these concepts should be interpreted and -most importantly- made operational seems far from being reached, and this ultimately prevents the L\&D issue from making significant progress.

\footnotetext{
${ }^{2}$ Indeed, this kind of more sophisticated and solidaristic responsibility (Conforti 2002), allows for sidestepping the stringency of the act-damage causal link required for state responsibility. With the primary aim being that of safeguarding victims, causality is more flexibly determined taking into account the complexity of the ecological system, including uncertainty, presence of multiple overlapping causes, and the temporal separation between act and damage (Barboza 2011).
} 
In this perspective, the compromise reached on article 8 of the Paris Agreement might be more fragile than it seems. Paragraph 52 of the accompanying decision states that the article should not 'involve or provide a basis for any liability or compensation' claims (UNFCCC 2015a). This formulation was the result of the diplomatic work carried out behind the scenes by the US and the small island representatives, in which the latter probably gave up the possibility of a legal remedy in order to have the $1.5^{\circ} \mathrm{C}$ temperature goal placed in the text. President Obama's pledge of a contribution of USD 30 million to climate risk insurance schemes in the Pacific, Central America and Africa (Rowling 2015) might also have contributed to paving the way for a compromise. The solution, however, was not supported by developing countries as whole and indeed marked a division among them with respect to the way L\&D should be advanced in climate talks. The Philippines expressed deep concern and Bolivia stated that 'no clause can deny people and countries' rights to ask for compensation' and that 'all the necessary institutional means will be used so that [climate] justice can be made' (Bolivia 2015). The issue of compensation might not be the 'elephant in the room' anymore. However, the statements by Bolivia and the Philippines suggest that -far from being settled- the dispute is likely to emerge again and play a role in the development of climate negotiations in the years to come.

\section{Conclusions}

Despite being one of the hottest topics to have emerged within climate negotiations in recent years, the issue of $L \& D$ still lacks a clear conceptualization. At the negotiation level, it has been the centre of a polarized and heated debate between the developing and developed world which has contributed little to developing a shared meaning. This paper has employed a critical discourse analytical approach to reconstruct and explain the different positions endorsed by Parties on $L \& D$, and to analyse how their interaction eventually resulted in the establishment of the WIM. It has traced the negotiating strategies of Parties up to the Warsaw and Paris Conferences, by identifying the legal, scientific and ethical arguments employed to support them. It has highlighted the ample reliance by the developing countries on legal reasoning and their framing of L\&D as a case of State Responsibility for wrongful acts. This paper has shown how the corollary concept of compensation, which has dominated the discussion since the early 1990's, may have been employed in a strategic way to obtain a formal legitimation of the L\&D discourse within the UNFCCC rather than a remedy per se. On the other hand, it has unveiled the defensive strategies put in place by the developed countries and the use of scientific knowledge and ethical considerations to neutralize the developing parties' requests.

The CDA carried out in this paper has not only aimed at 'making sense of the past' and explaining negotiating dynamics up to the present. Rather, its ambition has been to identify current stumbling blocks that need to be overcome to advance action on L\&D. The current disagreement on the positioning of L\&D vis-à-vis the adaptation space is 
surely one of them. The institutional advancements obtained on L\&D, as exemplified by the creation of the WIM and Article 8 of the Paris Agreement, in fact do not correspond to any comparable progress in its understanding. Without (political) agreement on its conceptual boundaries, meaningful action on L\&D will be eventually difficult to promote and the WIM will be confined to its explorative rather than operational mandate. Science and research can effectively support this process by providing relevant knowledge and contributing to neutralise the ideologisation of discourses. However, as the debate on climate change attribution shows, this role must be carefully undertaken. The politicisation of science, especially in policy domains where positions are polarised, is a concrete risk.

A second (and major) stumbling block lies in the connection of L\&D to other contested discourses under the UNFCCC, namely historical responsibility and differentiations. The issue of $L \& D$ has at its core a more general request for climate equity and justice that the UNFCCC has not yet addressed. This paper has therefore pointed out the importance of looking at the L\&D issue in a systemic way, connecting it to other discursive dynamics under the UNFCCC as well as to other relevant policy arenas where key Gordian knots that prevent action on L\&D could be cut.

Finally, this paper has highlighted the need for a deeper investigation of power dynamics within the UNFCCC. By employing a CDA, it has adopted a retro perspective approach and provided insights on the unfolding of power relations on L\&D up to the Paris agreement, analysing their current crystallisation within the WIM and identifying political barriers that need to be overcome. This can provide a useful basis on which future IR research can build upon. L\&D indeed represent an interesting case of the so-called structuralist paradox in negotiation (Zartman and Rubin 2002), that is the capacity of weaker negotiating parties (the developing countries, in this case) to negotiate with stronger ones and get significant results (e.g., the WIM). Future research is needed to identify the sources of negotiating power of the developing countries and to understand how these can evolve and impact future negotiation rounds. The ultimate objective should be to identify entry points for fostering international cooperation on $L \& D$, and thus contribute to the advancement of this complex, multifaceted issue. 


\section{References}

ActionAid. 2010. "Loss and Damage from Climate Change: The Cost for Poor People in Developing Countries.” Johannesburgh.

http://www.actionaid.org/sites/files/actionaid/loss_and_damage_-

_discussion_paper_by_actionaid-_nov_2010.pdf.

ActionAid/Care/WWF. 2012. "Tackling the Limits to Adaptation: An International Framework to Address 'Loss and Damage' from Climate Change Impacts.” Johannesburgh. http://www.care.org/sites/default/files/documents/CC-2012tackling_the_limits_lr.pdf.

2013. "Tackling the Climate Reality: A Framework for Establishing an International Mechanism to Address Loss and Damage at COP19.” Johannesburgh. http://www.actionaid.org/sites/files/actionaid/tackling_the_climate_reality.pdf.

ActionAid/Care/WWF/Germanwatch. 2012. "Into Unknown Territory: The Limits to Adaptation and Reality of Loss and Damage from Climate Impacts.” Johannesburgh. https://germanwatch.org/fr/download/4108.pdf.

Adger, W. Neil, Suraje Dessai, Marisa Goulden, Mike Hulme, Irene Lorenzoni, Donald R. Nelson, Lars Otto Naess, Johanna Wolf, and Anita Wreford. 2009. “Are There Social Limits to Adaptation to Climate Change?” Climatic Change 93 (3-4): 33554. doi:10.1007/s10584-008-9520-z.

ADP. 2015. “ADP 2-10. Working Document. Version of 8 September 2015 at 18:00.” Bonn, Germany.

AOSIS. 2008. "Proposal to the AWG-LCA Multi-Window Mechanism to Address Loss and Damage from Climate Change Impacts," 1-8. http://unfccc.int/files/kyoto_protocol/application/pdf/aosisinsurance061208.pdf.

_ 2013. "Statement Delivered by Nauru on Behalf of The Alliance of Small Island States (AOSIS). SBI Opening Plenary Warsaw.”

Barboza, Julio. 2011. The Environment, Risk and Liability in International Law. Leiden-Boston: Martinus Nijhoff Publishers.

Berridge, G.R., and A James. 2001. Dictionary of Diplomacy. Basingstoke: Palgrave.

Betzold, Carola. 2010. “'Borrowing’ Power to Influence International Negotiations: AOSIS in the Climate Change Regime, 1990-1997.” Politics 30 (3): 131-48. doi:10.1111/j.1467-9256.2010.01377.x.

Beyerlin, Ulrich, and Thilo Marauhn. 2011. International Environmental Law. Oxford: Bloomsbury Publishing.

Birkmann, Joern., and Torsten Welle. 2015. "Assessing the Risk of Loss and Damage : Exposure , Vulnerability and Risk to Climate-Related Hazards for Different Country Classifications.” International Journal of Global Warming 8 (2): 191212. 
Bolivia. 2015. “Intervención Bolivia COP21 - Ministro René Orellana.” https://www.youtube.com/watch?v=kQOEdNZBqFs.

CDKN. 2012. "Loss and Damage - From Defining to Understanding to Action.” http://cdkn.org/2012/09/loss-and-damage-from-defining-to-understanding-toaction/?loclang=en_gb.

Conforti, Benedetto. 2002. Diritto Internazionale. Napoli: Editoriale Scientifica.

Dow, Kirstin, Frans Berkhout, Benjamin L. Preston, Richard J. T. Klein, Guy Midgley, and M. Rebecca Shaw. 2013. "Limits to Adaptation.” Nature Climate Change 3 (4): 305-7. doi:10.1038/nclimate1847.

ENB. 2013a. "Summary of the Warsaw Climate Change Conference:11-23 November 2013.” Vol. 12. Winnipeg, Manitoba, Canada.

—_. 2013b. “Warsaw Highlights: Friday, 15 November 2013.” Winnipeg, Manitoba, Canada.

__. 2013c. “Warsaw Highlights: Saturday, 16 November 2013.” Winnipeg, Manitoba, Canada.

—. 2013d. “Warsaw Highlights: Wednesday, 20 November 2013.” Winnipeg, Manitoba, Canada.

- 2014. "Summary of the Lima Climate Change Conference: 1-14 December 2014.” Vol. 12. Winnipeg, Manitoba, Canada.

EU. 2013. "Statement at the Opening of the High-Level Segment of COP19 by Connie Hedegaard and Valentinas Mazuronis on Behalf of the EU and Its Member States." http://unfccc.int/files/meetings/warsaw_nov_2013/statements/application/pdf/cop1 9_hls_european_union.pdf.

Fairclough, Norman. 1992. Discourse and Social Change. Discourse. Vol. 54. Polity Press. http://umass.worldcat.org.silk.library.umass.edu/title/discourse-and-socialchange/oclc/25371774\&referer=brief_results.

. 2003. Analysing Discourse: Textual Analysis for Social Research. London and New York: Routledge Taylor and Francis Group. http://books.google.com/books?id=5-gXEMPINsEC\&pgis=1.

Fairclough, Norman, and Ruth Wodak. 1997. “Critical Discourse Analysis.” In Discourse Studies: A Multidisciplinary Introduction, 2: Discour:258-81.

Farrands, Chris, Imad El-Anis, and Lloyd Pettiford. 2015. A New A-Z of International Relations Theory. Edited by Lloyd Pettiford. London, New York: I.B. Tauris \& Co. Ltd.

Fekete, Alexander, and Patrick Sakdapolrak. 2014. "Loss and Damage as an Alternative to Resilience and Vulnerability? Preliminary Reflections on an Emerging Climate Change Adaptation Discourse.” International Journal of Disaster Risk Science 5 (1): 88-93. doi:10.1007/s13753-014-0012-7. 
Friman, Mathias. 2007. “Historical Responsibility in the UNFCCC.” http://liu.divaportal.org/smash/get/diva2:233089/FULLTEXT01.pdf.

—. 2013. "Historical Responsibility: Assessing the Past in International Climate Negotiations.” Linköping University.

Friman, Mathias, and Mattias Hjerpe. 2015. “Agreement, Significance, and Understandings of Historical Responsibility in Climate Change Negotiations.” Climate Policy 15 (3): 302-20. doi:10.1080/14693062.2014.916598.

G77 and China. 2013. “Approaches to Address Loss and Damage Associated with Climate Change Impacts in Developing Countries That Are Particularly Vulnerable to the Adverse Effects of Climate Change to Enhance Adaptive Capacity. Submission from the Group of 77 and China.” http://unfccc.int/resource/docs/2013/sbi/eng/crp01.pdf.

Hafner-Burton, Emily M., David G Victor, and Yonatan Lupu. 2012. "Political Science Research on International Law: The State of the Field.” The American Journal of International Law 106 (1): 47-97.

Hesse-Biber, Sharlene Nagy, and Patricia Leavy. 2011. The Practice of Qualitative Research. 2nd ed. SAGE.

Hoffmaister, P. J., M. Talakai, P. Damptey, and A. S. Barbosa. 2014. "Warsaw International Mechanism for Loss and Damage: Moving from Polarizing Discussions towards Addressing the Emerging Challenges Faced by Developing Countries.” Loss and Damage in Vulnerable Countries Initiative. Bonn, Germany. http://www.lossanddamage.net/.

Huggel, Christian, Dáithí Stone, Maximilian Auffhammer, and Gerrit Hansen. 2013. "Loss and Damage Attribution.” Nature Climate Change 3 (8). Nature Publishing Group: 694-96. doi:10.1038/nclimate1961.

Huq, Saleemul, Erin Roberts, and Adrian Fenton. 2013. "Loss and Damage.” Nature Climate Change 3 (11). Nature Publishing Group: 947-49. doi:10.1038/nclimate2026.

Hyvarinen, Joy. 2012. "Loss and Damage Caused by Climate Change : Legal Strategies for Vulnerable Countries.” London, UK.

IPCC. 2012. "Managing the Risks of Extreme Events and Disasters to Advance Climate Change Adaptation (summary)."

— 2013. “Climate Change 2013: The Physical Science Basis. Contribution of Working Group I to the Fifth Assessment Report of the Intergovernmental Panel on Climate Change.” Stocker, T.F., D. Qin, G.-K. Plattner, M. Tignor, S.K. Allen, J. Boschung, A. Nauels, Y. Xia, V. Bex and P.M. Midgley (eds.). Cambridge University Press, Cambridge, United Kingdom and New York, NY, USA. doi:10.1017/CBO9781107415324. 
2014. "Working Group II Contribution to the IPCC Fifth Assessment Report (AR5), Climate Change 2014: Impacts, Adaptation and Vulnerability.”

Ireland. 2013. “Address by Mr. Phil Hogan, T.D., Minister for the Environment, Community and Local Government, Ireland at COP 19, Warsaw, 20th November 2013.”

James, Rachel, Friederike Otto, Hannah Parker, Emily Boyd, Rosalind Cornforth, Daniel Mitchell, and Myles Allen. 2014. "Characterizing Loss and Damage from Climate Change.” Nature Climate Change 4 (November 2014): 938-39.

Janks, Hilary. 1997. "Critical Discourse Analysis as a Research Tool.” Discourse: Studies in the Cultural Politics of Education 18 (3): 329-42. doi:10.1080/0159630970180302.

Jorgensen, Marianne, and Louise J Phillips. 2002. "Discourse Analysis as Theory and Method.” Theory 11 (4): 229. doi:10.1177/0959354301114006.

Linnerooth-bayer, Joanne, M. J. Mace, and Reinhard Mechler. 2013. “Proposal for Insurance for Facilitation of Adaptation.” In Climate Change Negotiations, edited by Gunnar Sjostedt and Ariel Penetrante, 374-89. Oxon: Routledge.

Linnerooth-bayer, Joanne, M. J. Mace, and Roda Verheyen. 2003. "Insurance-Related Actions and Risk Assessment in the Context of the UNFCCC.”

Mathew, L. M., and Sonia Akter. 2015. "Loss and Damage Associated with Climate Change Impacts.” In Handbook of Climate Change Mitigation and Adaptation, edited by W.-Y. Chen, J. Seiner, T. Suzuki, and M. Lackner, 1st ed., 1-23. New York: Springer.

Mayer, Benoît. 2014. "Whose ' Loss and Damage'? Promoting the Agency of Beneficiary States.” Climate Law 4 (3-4): 267-300.

McNamara, Karen Elizabeth. 2014. "Exploring Loss and Damage at the International Climate Change Talks.” International Journal of Disaster Risk Science 5 (3): 24246. doi:10.1007/s13753-014-0023-4.

Mechler, Reinhard, Laurens M Bouwer, Joanne Linnerooth-bayer, Stefan Hochrainerstigler, Jeroen C J H Aerts, Swenja Surminski, and Keith Williges. 2014. “Managing Unnatural Disaster Risk from Climate Extremes.” Nature Climate Change 4 (April): 235-37. doi:10.1038/nclimate2137.

Meyer, Michael. 2001. "Between Theory, Method, and Politics: Positioning of the Approaches to CDA.” In Methods of Critical Discourse Analysis, edited by Ruth Wodak and Michael Meyer, 14-31. London, Thousand Oaks, New Delhi: SAGE Publications. doi:10.1017/CBO9781107415324.004.

Norway. 2013. "Institutional Arrangements under the UNFCCC for Approaches to Address Loss and Damage Associated with Climate Change Impacts in Developing Countries That Are Particularly Vulnerable to the Adverse Effects of 
Climate Change to Enhance Adaptive Capacity.”

https://unfccc.int/files/adaptation/application/pdf/norway_l_d.pdf.

Pedersen, Ove. 2009. “Discourse Analysis.” 65. Copenhagen.

http://openarchive.cbs.dk/bitstream/handle/10398/7792/WP CBP 2009-

65.pdf?sequence $=1$.

Pehar, D. 2011. "Use of Ambiguities in Peace Agreements.” In Language and Diplomacy, edited by J Kubalija and H. Slavik, 153-62. Malta: DiploProjects.

Roberts, Erin, and Saleemul Huq. 2015. "Coming Full Circle : The History of Loss and Damage under the UNFCCC.” International Journal of Global Warming 8 (2): $141-57$.

Rowling, Megan. 2015. “Obama Unveils \$30 Mln for Climate Risk Insurance to Protect Poor.” Reuters. http://www.reuters.com/article/climatechange-summit-insuranceidUSL8N13Q3S320151201.

Russian Federation. 2013. "Russian Federation Statement Made by Alexander Bedritsky, Advisor to the President, Special Envoy for Climate.” http://unfccc.int/files/meetings/warsaw_nov_2013/statements/application/pdf/cop1 9_hls_russia.pdf.

Stabinsky, Doreen, and Juan P. Hoffmaister. 2015. "Establishing Institutional Arrangements on Loss and Damage under the UNFCCC : The Warsaw International Mechanism for Loss and Damage.” International Journal of Global Warming 8 (2).

Stevenson, Angus. 2011. Oxford Dictionary of English. Edited by Angus Stevenson. Oxford University Press. Vol. 2012. Oxford University Press. doi:10.1093/acref/9780199571123.001.0001.

Tol, Richard S.J, and Roda Verheyen. 2004. "State Responsibility and Compensation for Climate Change Damages—a Legal and Economic Assessment.” Energy Policy 32 (9): 1109-30. doi:10.1016/S0301-4215(03)00075-2.

Umbrella Group. 2013. “Statement at COP19/CMP9 by New Zealand for the Umbrella Group.”

http://unfccc.int/files/meetings/warsaw_nov_2013/statements/application/pdf/cop1 9_hls_new_zealand_umbrella_group.pdf.

UNFCCC. 2008. "Report of the Conference of the Parties on Its Thirteenth Session, Held in Bali from 3 to 15 December 2007." http://unfccc.int/resource/docs/2007/cop13/eng/06a01.pdf. . 2011a. “(FCCC/SBI/2011/MISC.1) Views and Information on the Elements to Be Included in the Work Programme on Loss and Damage,” no. April: 1-21.

. 2011b. “(FCCC/SBI/2011/MISC.8) Synthesis Report on Views and Information on the Thematic Areas in the Implementation of the Work 
Programme.” Note by the Secretariat, no. September: 1-16.

. 2011c. "Report of the Conference of the Parties on Its Sixteenth Session, Held in Cancun from 29 November to 10 December 2010 Addendum.”

. 2012a. “(FCCC/SBI/2012/MISC.14) Views and Information from Parties and Relevant Organizations on the Possible Elements to Be Included in the Recommendations on Loss and Damage in Accordance with with Decision 1/CP.16.” Submissions from Parties and Relevant Organizations-Addendum, no. October: 1-20.

. 2012b. "(FCCC/SBI/2012/MISC.14/Add.1) Views and Information from Parties and Relevant Organizations on the Possible Elements to Be Included in the Recommendations on Loss and Damage in Accordance with Decision 1/CP.16.” . 2012c. “(FCCC/SBI/2012/MISC.14/Add.2) Views and Information from Parties and Relevant Organizations on the Possible Elements to Be Included in the Recommendations on Loss and Damage in Accordance with Decision 1/CP.16.” Submissions from Parties and Relevant Organizations-Addendum, no. November: $1-7$.

- 2012d. "A Literature Review on the Topics in the Context of Thematic Area 2 of the Work Programme on Loss and Damage : A Range of Approaches to Address Loss and Damage Associated with the Adverse Effects of Climate Change Note by the Secretariat.” Bonn, Germany.

. 2013a. "Approaches to Address Loss and Damage Associated with Climate Change Impacts in Developing Countries That Are Particularly Vulnerable to the Adverse Effects of Climate - Activities to Be Undertaken under the Work Programme. Draft Conclusions Proposed by T.”

. 2013b. "Warsaw International Mechanism for Loss and Damage Associated with Climate Change Impacts. Proposal by the President (FCCC/CP/2013/L.15).”

- 2014a. “Decision 2/CP.19.” In Report of the Conference of the Parties on Its Nineteenth Session, Held in Warsaw from 11 to 23 November 2013, 1-43. http://unfccc.int/resource/docs/2013/cop19/eng/10a01.pdf.

- 2014b. "Report of the Conference of the Parties on Its Nineteenth Session, Held in Warsaw from 11 to 23 November 2013.” http://unfccc.int/resource/docs/2013/cop19/eng/10a01.pdf.

_ 2015a. Adoption of the Paris Agreement.

http://unfccc.int/resource/docs/2015/cop21/eng/109r01.pdf.

—. 2015b. “Draft Paris Outcome, 5 December 2015.” Paris. http://unfccc.int/resource/docs/2015/adp2/eng/106r01.pdf.

van Dijk, T.A. 2001. “The Handbook of Discourse Analysis.” In Handbook of Discourse Analysis, edited by D. Shiffrin and H. Hamilton D. Tannen, 352-71. 
Oxford: Blackwell Publishing.

Verheyen, Roda. 2012. “Loss \& Damage : Tackling Loss \& Damage.” Loss and Damage in Vulnerable Countries Initiative. Bonn, Germany.

. 2015. "Loss and Damage due to Climate Change : Attribution and Causation Where Climate Science and Law Meet.” International Journal of Global Warming 8 (2): 158-69.

Warner, Koko, and Kees van der Geest. 2013. "Loss and Damage from Climate Change : Local-Level Evidence from Nine Vulnerable Countries.” International Journal of Global Warming 5 (4).

—. 2015. "Editorial : Loss and Damage from Climate Change : Emerging Perspectives.” International Journal of Global Warming 8 (2): 133-40.

Warner, Koko, and S.A. Zakieldeen. 2011. "Loss and Damage due to Climate Change: An Overview of the UNFCCC Negotiations.” Oxford.

http://www.oxfordclimatepolicy.org/publications/documents/LossandDamage.pdf.

Waugh, Linda R, Theresa Catalano, Khaled Al Masaeed, Tom Hong Do, and Paul G Renigar. 2015. "Critical Discourse Analysis: Definition, Approaches, Relation to Pragmatics, Critique, and Trends.” In Interdisciplinary Studies in Pragmatics, Culture and Society, edited by Alessandro Capone and Jacob L. Mey, 71-135. Springer International Publishing. doi:10.1007/978-3-319-12616-6.

Wentz, Jessica, and Michael Burger. 2015. "Designing a Climate Change Displacement Coordination Facility : Key Issues for COP 21.” Sabin Center for Climate Change Law.

Wodak, Ruth. 2001. "What CDA Is About. A Summary of Its History, Important Concepts and Its Developments.” In Methods of Critical Discourse Analysis, edited by Ruth Wodak and Michael Meyer, 1-13. London, Thousand Oaks, New Delhi: SAGE Publications.

Zartman, I. William, and Jeffrey Z. Rubin. 2002. Power and Negotiation. University of Michigan Press. 